Urbanek P., Institutional determinants of remuneration policy transparency in the banking sector in Poland, „Ekonomia i Prawo. Economics and Law”, Polszakiewicz B., Boehlke J. (ed.), Vol. 14, No. 4/2015, pp. 491-502. DOI: http://dx.doi.org/10.12775/EiP.2015.032.

\title{
INSTITUTIONAL DETERMINANTS OF REMUNERATION POLICY TRANSPARENCY IN THE BANKING SECTOR IN POLAND
}

\author{
SUMMARY
}

This article aims to assess the factors determining the level of transparency of executive compensation policies in Polish public banks. Two groups of institutional factors affecting the propensity of banks to disclose information on various aspects of the remuneration policy have been analyzed. The first group is associated with the response of banks to the financial crisis of 2007-2008. Increase of compensation transparency during this period may have been a result of pressure coming from informal capital market institutions. The second group concerns changes in formal institutions - the legal system, which took place after 2011. The research tool used to assess the role of these two groups of institution is an index of remuneration policy transparency. The survey was conducted for the period 2005-2013 on a sample of 16 banks listed on the Warsaw Stock Exchange.

Keywords: compensation policy; banking sector; financial crisis

JEL Classification: G2; G3; K2

"Piotr Urbanek, University of Łódź, Faculty of Economics and Sociology, Department of Institutional Economics, ul. Rewolucji 1905 r. 41/43, 90-214 Łódź, Poland, phone: +48 4263551 06, e-mail: piotrur@uni.lodz.pl. 


\section{INTRODUCTION}

Transparency of corporation is one of the key attributes of corporate governance. Free access to information showing a comprehensive picture of intra-corporate relations is treated as a determinant of the ability to assess the quality of management and supervisory processes in the company. The postulate to increase the transparency of corporations appears in all legal and industry-based regulations aimed at improving corporate governance standards.

The experience of the recent financial crisis shows the importance of the principles of remuneration of chief executives for the stable functioning of financial markets. It is generally accepted that the ineffective remuneration policy was one of the key factors that have led to the crisis. In response to this problem numerous attempts were made to reform the remuneration policy for top executives in financial sectors. The increase the transparency of this policy was one of the elements of these reforms.

An attempt is made in this paper to assess the factors determining the level of transparency of executive compensation policy in public banks in Poland. Two groups of institutional factors affecting the propensity of banks to disclose information on various aspects of remuneration policy have been analyzed. The first group is associated with the response of banks to the financial crisis of 2007-2008. The increase of compensation transparency during this period may have been a result of pressure in the banking sector coming from informal institutions. The second group concerns changes in formal institutions - the legal system, which took place after 2011. The research tool used to assess the role of these two groups of institutions is an index of remuneration transparency policy. The survey was conducted for the period 2005-2013 on a sample of 16 banks listed on the Warsaw Stock Exchange.

\section{REMUNERATION TRANSPARENCY AS A CORPORATE GOVERNANCE STANDARD}

The postulate of high transparency of chief executives remuneration aims to improve the functioning of the labor market of managers. Market control functions can be effectively implemented on condition that the high transparency is ensured. The valuation of services provided by principal officers in companies requires access to information on the principles, the amount, and structure of remuneration of managers in other compara- 
ble companies. This is based on the conviction that well-informed shareholders and capital markets can exert pressure on company boards, causing them to create effective remuneration systems to maintain good relations between the income achieved by the managers and the benefits of shareholders and other stakeholders of the company. This refers to the informal institutions of reputation and social control, in line with the principle of "name and shame".

The benefits resulting from the disclosure of relevant information relating to executive compensation policy are obvious. However, one must also point to the costs this entails. Making the "how much the boss earns" public affects the amount of contracts concluded with other workers and introduces unnecessary emotions in wage negotiations with trade unions ${ }^{1}$. This also provides sensational topics for the media, which are happy to deliberate astronomical earnings of CEOs of major corporations. The natural reaction of company boards would be to limit wages, even in a situation where the company's results would justify such payments. On the other hand, a high transparency of compensation creates specific wage brackets in labor market of managers and the natural desire to achieve the highest possible salary in the group of comparable companies. These two tendencies can effectively disrupt the occurrence of a key dependence linking the amount of compensation with company's performance.

The essence of disclosure and transparency of the corporation involves the possibility to implement the primary task, which is to provide investors with comparable information on the company's operations, regardless of the country and sector in which they operate. Di Piazza and Eccles presented the idea of the three-tier model of corporate transparency ${ }^{2}$. The first tier relates to generally accepted accounting principles, (IFRS, IAS, GAAP). Such standards make it easy for companies to access international capital markets, while investors can objectively assess companies, regardless of the area of their operation. The second tier should define sectoral, financial, and nonfinancial standards. The need to develop the standards results from the fact that the key value generators vary depending on the sector in which a company works. The third tier refers to a specific company and information disclosing its strategies, plans, budgets, risk management, corporate governance rules, wage policy, standards for assessing effectiveness, etc.

${ }_{1}$ P. Urbanek, Wynagrodzenia zarzqdu w spótkach kapitatowych, PWE, Warszawa 2006, p. 111.

2 S.A. Di Piazza, R.G. Eccles, Building Public Trust: The Future of Corporate Reporting, John Wiley \& Sons, 2003. 
A similar hierarchy of transparency standards could be proposed in the area of remuneration policy for managers. The first, the most general level should include the range of disclosures applicable to all companies, regardless of their national and sectoral specificity. This includes description of the most important procedures associated with the remuneration policy used in the company, the amount of compensation of principal officers, the structure of remuneration broken down into fixed and variable, short-term and longterm components, schemes for participation in the ownership for managers, severance payments, non-cash benefits, etc. Sectoral standards at the second level of disclosures should include factors fundamental to operators in the sector and must be taken into account in building effective systems of remuneration. An example would be the banking sector, in which to effectively motivate managers it is necessary to take into account in the remuneration policy procedures to identify, evaluate, measure, and monitor risks. The third level refers to company specific disclosures. In contrast to the previous two, they may be optional and based on the need to create by the company additional channels of communication with shareholders and capital markets. Another motive for voluntary disclosures may involve the desire to avoid the potential pressure on part of the regulators.

\section{TRANSPARENCY AND INSTITUTIONS}

Corporate transparency has been the subject of numerous studies. Assessing the tendency of companies to disclose information on the rules of their operation it is frequently stressed that it is primarily determined by the quality of corporate governance standards used in the company. This should include such aspects of supervision and characteristics of the company as the size and composition of the company board, the functioning of committees within the board, the degree of ownership concentration and the form of control over the company, the share of institutional investors, the size of the company etc. Such determinants can be used to explain differences in the level of transparency existing between various companies.

Another approach to evaluation of the phenomenon of transparency should be applied in a situation where the subject of analysis is not a single company, and we are interested in how the transparency of the corporation changes in a certain period of time and the study concerns the group of entities. This means that the purpose of the study is to assess the institutional conditions of transparency and therefore it is important to define the concept of institution. Considering the research context adopted in the paper we can 
say that "An institution is defined as collective action in control, liberation and expansion of individual action"3. Another approach defines institutions as "regularity in social behavior (...) which governs economic behavior in strictly defined recurring situations. Social institution implies the mechanism of selfcontrol, or control must be exercised by an external power"4. An important element of the concept of institutions is their division into formal and informal institutions. The former refer to legal standards regulating the functioning of the economy. Informal institutions are "the rules of conduct contained in customs, traditions, routine, beliefs, or the mentality of the individual" 5 .

This division can be the starting point for identifying factors prompting banks to disclose information on remuneration policy. This is firstly due to legal regulations which require companies to publish a particular set of information. In the model of transparency presented in the preceding paragraph this refers to disclosures at the first two levels. The third level means company specific disclosures. In contrast to the previous two, these can be optional and based on the company's need to create additional channels of communication with shareholders, stakeholders and capital markets. Another motive for voluntary disclosures may be the desire to avoid possible pressure on part of regulators or expectations of financial markets. It can be concluded that such disclosures may be an effect of informal institutions - ethical principles, reputation, trust, corporate culture, rules of social intercourse etc.

Taking into account the causes and course of the recent financial crisis, it seems that so identified informal institutions might have had a significant impact on the propensity of the financial sector entities to disclose information on the executive compensation policy in the period after the outbreak of the crisis. Ineffective remuneration policy has been widely recognized as one of the main reasons which encourage bank executives to engage in high-risk business ventures, which in effect led to the instability of financial markets. In this situation, one of the factors which could restore confidence in banks was high transparency of principles of remuneration of top managers.

${ }^{3}$ J. Commons, Institutional Economics, “American Economic Review”, Vol. 21/1931, p. 648 [quoted after:] J. Godłów-Legiędź, Wspótczesna ekonomia. Ku nowemu paradygmatowi, C.H.Beck, Warszawa 2010, p. 66.

${ }^{4}$ A. Schotter, The Economic Theory of the Social Institutions, Cambridge University Press, Cambridge 2008, p. 11 [quoted after:] J. Godłów-Legiędź, op. cit., p. 66.

5 S. Rudolf, Nadzór korporacyjny w świetle analizy instytucjonalnej, [in:] S. Rudolf (ed.), Nowa ekonomia instytucjonalna wobec wspótczesnych problemów gospodarczych, WSEPiNM, Kielce 2014, p. 156. 
The role of this type of informal institutions during the crisis resulted also from the fact that for many years in Poland there were no specific regulations on corporate governance standards related to disclosure of remuneration policy, which were dedicated to the financial sector institutions. Practices in this respect were regulated in the same way for all enterprises, with particular emphasis on public companies. The legislation was the source of regulations - laws and regulations - as well as - principles of corporate governance applicable to listed companies.

The first recommendations on the disclosure of information relating to remuneration of executives appeared in the first version of the Polish Corporate Governance Code of 2002. In subsequent versions of codes the recommendations on the transparency evolved. More precise requirements concerning disclosures appeared in the principles of good practice introduced in 2010 and again in $2012^{6}$. This was the consequence of the implementation of the European Commission Recommendation of 14 December 2004 fostering an appropriate regime for the remuneration of directors of listed companies (2004/913/EC) supplemented by the recommendation of the European Commission of 30 April 2009.(2009/385/EC). The reference to the EU regulations definitely changed the status of statutory recommendations on executive remuneration policy. All key areas of the policy related to transparency of remuneration found their way into the area of these regulations.

A similar course of evolution of regulations regarding the remuneration policy of senior executives in banks occurs in the area of "hard law" - laws and regulations. Until 2011 the institutions responsible for the supervision of financial markets in Poland have not recognized the need to include special regulations on remuneration policy in banks. In response to the CRD III Directive of the European Parliament including the provisions relating to transparency of remuneration in banks, the Polish Financial Supervision

${ }^{6}$ Appendix to: Uchwata Nr 17/1249/2010 Rady Nadzorczej Gietdy Papierów Wartościowych w War-szawie S.A. z dnia 19 maja 2010 roku w sprawie uchwalenia zmian "Dobrych Praktyk Spótek Notowanych na GPW" (Resolution No. 17/1249/2010 of the Warsaw Stock Exchange Supervisory Board of 19 May 2010 concerning adoption of amendments to "Code of Best Practice for WSE Listed Companies") and Uchwata Nr 19/1307/2012 Rady Nadzorczej Gietdy Papierów Wartościowych w War-szawie S.A. z dnia 21 listopada 2012 r. w sprawie uchwalenia zmian "Dobrych Praktyk Spótek Notowanych na GPW” (Resolution No. 19/1307/2012 of the War-saw Stock Exchange Supervisory Board of 21 November 2012 concerning adoption of amendments to "Code of Best Practice for WSE Listed Companies"). 
Authority (KNF) issued in October 2011 the Resolution governing the transparency of remuneration ${ }^{7}$.

Under these provisions, the bank shall make public information on variable remuneration components policy for persons holding managerial positions including: information on the policy-making process for variable remuneration components, performance measurement criteria and adjustment of the performance by the risk, the main parameters and rules for determining the remuneration of persons holding managerial positions in the bank, aggregate quantitative information on remuneration broken down by business lines used in the management of the bank.

Comparison of solutions concerning the scope of disclosures which found their way into various regulations shows a lack of consistency. The KNF Regulation places emphasis on disclosure issues to a greater extent on the principles of operation of remuneration policy rather than on detailed information relating to the amount of the remuneration of top officers of banks, with further division into various components of remuneration. Meanwhile, the Principles of Good Practices include unambiguous provisions obliging companies to present detailed information about remuneration for individual managers. This inconsistency of regulations means that banks can interpret the requirements for transparency in different ways. The informative transparency of remuneration policy in banks in Poland is additionally not clear enough because none of the regulations includes the demand to present information on remuneration in the form of a standard report, with a common format for all entities which have to draw it up.

\section{RESEARCH METHOD AND RESEARCH SAMPLE}

The assessment of institutional conditions of remuneration transparency policy was conducted on a sample of 16 public banks listed on the Warsaw Stock Exchange. The study period covered the years 2005-2013. The information used in the study was collected from the banks' annual reports.

7 Uchwata Nr 259/2011 Komisji Nadzoru Finansowego z dnia 4 października 2011 r. zmieniajaca uchwate w sprawie szczegótowych zasad i sposobu ogtaszania przez banki informacji o charakterze jakościowym i ilościowym dotyczacych adekwatno-ści kapitatowej oraz zakresu informacji podlegajacych ogtaszaniu, Dz. Urz. KNF Nr. 8, poz. 39 (Resolution No. 259/2011 of the Polish Financial Supervision Au-thority of 4 October 2011 amending the Resolution on detailed rules and methods of publication of qualitative and quantitative information on capital adequacy by banks and the scope of published information, OJ of the KNF No. 8, item 39). 
Transparency of remuneration policy was determined based on the aggregate transparency index (ATI), developed based on information on remuneration disclosed by banks in annual reports ${ }^{8}$. The aggregate transparency index is the sum of four sub-indices containing information on:

1. amount and structure of remuneration,

2. remuneration policy in regard to variable components of remuneration,

3. remuneration committees,

4. long-term incentive programs (LTIP).

For each sub-index the information was collected on selected aspects of remuneration policy in each of these areas. The first two sub-indices contain 12 and 9 variables respectively, in line with mandatory disclosure categories, according to the Resolution 259/2011 of the Polish Financial Authority dated 4 October 2011. The third index, the remuneration committees, includes 6 variables on the principles of operation of committees which are consistent with the provisions of CRD III, but which were not directly adopted in Poland. The last index contains 11 variables which can be the basis for assessing the scale of the use of LTIP.

All variables used to construct the sub-indices are of zero-one nature and are so selected that a higher index value indicates a higher level of transparency in this area of remuneration policy, which is described by the index. Since the number of variables in sub-indices differs, they were standardized by dividing the number of variables disclosed by the bank by the maximum number of variables for particular index. This means that that the value of sub-index shows the share of information disclosed by banks in each of the described aspects of remuneration policy. The ATI value is the sum of sub-indices and is within the range of (0.4). The higher the ATI the higher the level of transparency of remuneration policy exists in the bank.

Table 1. Sub-indices of transparency

\begin{tabular}{|c|c|c|}
\hline SUB-INDICES & THE NUMBER OF VARIABLES & SOURCE OF DISCLOSURES \\
\hline 1. The amount and structure of remuneration & 12 & $\begin{array}{c}\text { Mandatory, defined in Resolution } \\
259 / 2011 \text { of the Polish Financial Supervi- } \\
\text { sion Authority. }\end{array}$ \\
\hline $\begin{array}{c}\text { 2. Remuneration policy in regard to variable } \\
\text { components of remuneration }\end{array}$ & 9 & Consistent with the provisions of CRD III. \\
\hline 3. Remuneration committees & 6 & Voluntary \\
\hline 4. Long-term incentive programs & 11 & \multicolumn{1}{|c|}{. }
\end{tabular}

Source: Author's own compilation.

8 The method of construction of the ATI is described in A. Słomka-Gołębiowska, P. Urbanek, Wptyw nadzoru korporacyjnego na transparentnośc polityki wynagradzania kadry kierowniczej w bankach w Polsce, "Gospodarka Narodowa", Vol. 4/2015. 
Considering sources of disclosures for all sub-indices, since 2012, these are formal institutions for the first two indices, legal regulations introduced by the Polish Financial Supervision Authority (table 1). The information contained in the last index is voluntary, which means that banks can decide on this type of disclosure under the influence of informal institutions. In the case of the remuneration committee index recommendation to present such information is still not mandatory in Poland. Therefore it is not clear what motivates banks to disclose the principles of operation of committees. This may be the pressure of a formal nature resulting from the desire to adapt to regulations which soon may come into force, or the desire to inform stakeholders that the bank has implemented the solution commonly considered to be a good corporate governance standard.

\section{FINDINGS}

Given the period covered by the study and the institutional conditions of transparency identified in the preceding paragraphs it would be expected that the level of the specified indexes will exhibit significant growth in the two periods. The first one covers the period of the last financial crisis from 2008 to 2009. During this period, banks should be interested to increase the scope of executive compensation disclosure in response to the expectations of capital markets, institutions responsible for supervising markets, stakeholders, and in particular, depositors. This type of behavior of the financial sector entities would be aimed at recovering public trust and would have its origin in the pressure exerted by informal institutions. Changes in the level of transparency which have taken place since 2012 have been caused by the introduction of new regulations imposing a much greater disclosure requirements on banks.

The results presented in table 2 show the average values of indices of transparency of remuneration policy in the surveyed banks for the period 2005-2013. Analysis of the changes taking place for individual indices allows an assessment of the impact of the two groups of institutions. 
Table 2. The average value of aggregate transparency index and transparency sub-indices

\begin{tabular}{|c|c|c|c|c|c|c|c|c|c|}
\hline & 2005 & 2006 & 2007 & 2008 & 2009 & 2010 & 2011 & 2012 & 2013 \\
\hline ATI & 0.74 & 0.94 & 1.19 & 1.33 & 1.32 & 1.40 & 1.62 & 2.34 & 2.52 \\
\hline 1 & 0.38 & 0.40 & 0.39 & 0.41 & 0.42 & 0.46 & 0.48 & 0.57 & 0.62 \\
\hline 2 & 0.03 & 0.03 & 0.03 & 0.03 & 0.02 & 0.06 & 0.10 & 0.50 & 0.66 \\
\hline 3 & 0.13 & 0.28 & 0.39 & 0.46 & 0.48 & 0.46 & 0.55 & 0.72 & 0.67 \\
\hline 4 & 0.25 & 0.30 & 0.37 & 0.42 & 0.40 & 0.42 & 0.49 & 0.55 & 0.57 \\
\hline
\end{tabular}

ATI — Aggregated transparency index; sub-indices: 1 - Amount and structure of remuneration, 2 - Variable components of remuneration; 3 - Remuneration committee; 4 - Long-term incentive programs.

Source: Author's own compilation.

The first of the analyzed indices is an aggregate index of transparency. Its changes in the period under study show that the Polish public banks disclose an increasing scope of information on remuneration policy. The index value more than tripled from 0.74 in 2005 to a level of 2.52 in 2013. For the two periods, for which one would expect the index to increase significantly due to the impact of informal institutions (2008-2009) and formal institutions (2012-2013), the index increased definitely stronger in the second period. This means that banks began to conduct a more transparent remuneration policy not as a result of their grass-roots initiatives aimed at restoring confidence lost in response to the financial crisis, but due to legislative pressure exerted by financial market regulators.

The greatest changes in sub-indices can be observed for variable components of remuneration. Until 2011, banks disclosed, on average, less than 5\% of the information which was used to construct the index. The significant increase in transparency in this area of remuneration policy did not take place until 2012 and it was the inevitable reaction to the new, more stringent regulations. In the case of this index it can therefore be concluded that informal institutions had virtually no effect on the scope of disclosures.

A slightly different interpretation should be taken in assessing the index for LTIP. Since 2012, banks in Poland have been obliged to use of such remuneration instruments. At the same time the regulations on disclosures were not introduced. This means that the information which is presented by the banks in their annual reports is optional. In this context, one should note the high level of this index. Despite the lack of formal institutions, over the period under study banks disclosed on average more than $40 \%$ of the information used to construct the index.

Remuneration committee index should be assessed in a similar way. In 2005, its level was relatively low because the banks presented slightly more 
than $10 \%$ of the information contained in the index. In subsequent years, the level of the index increased significantly reaching a value of 0.72 in 2012 . Here again, disclosures are not to the effect of regulations obliging banks to such reporting. This can be explained by the fact that certain models of disclosures are contained in EU regulations that will soon be implemented in the Polish legislative system. Therefore, by presenting this kind of information banks in some measure anticipate the new information requirements.

The greatest stability in the analyzed period was presented by the amount and structure of remuneration index. Before the Polish Financial Supervision Authority introduced new standards of transparency banks disclosed about $40 \%$ of information included in the index. During the financial crisis, virtually no changes took place. From 2012 the index rose by less than 10\%. In this case, once again we can say that, the impact of institutions, both formal and informal, was relatively weak.

\section{CONCLUSIONS}

Transparency of companies is determined by a number of factors. In addition to the corporate governance standards used in companies, which differentiate the level of transparency between various entities, the propensity for public disclosure of information on principles of operation of companies is strongly affected by factors of an institutional nature, which in the same way affect all entities operating in the sector.

An attempt is made in this paper to assess the role of two groups of institutions which can affect the level of transparency of remuneration policy in public banks in Poland. These include formal institutions related to legal regulations and informal institutions related to pressure exerted on companies by financial markets, shareholders, stakeholders, and regulators.

Studies conducted for the years 2005-2013 show that the recent financial crisis was not a specific milestone affecting a significant increase in transparency of remuneration policies in banks. Banks have taken virtually no grassroots action to create an additional channel to communicate with business environment in order to restore confidence in the financial sector. This applies to all the areas of transparency under study. As far as formal institutions are concerned only in the case of variable remuneration components significant improvement of transparency was observed. After the Polish Financial Supervision Authority introduced new regulations, banks began to disclose much more information than it was before. At the same time, however, it should be emphasized that still the level of disclosures reaches approximate- 
ly $70 \%$ of the information required by law. Firstly, this indicates the inconsistency of these regulations and difficulty in their unambiguous interpretation. Secondly, it shows the weakness of the institutions responsible for the supervision of financial markets in terms of enforcement of these regulations.

\section{BIBLIOGRAPHY}

Commons J., Institutional Economics, "American Economic Review", Vol. 21/1931.

Di Piazza S.A., Eccles R.G., Building Public Trust: The Future of Corporate Reporting, John Wiley \& Sons, 2003.

Godłów-Legiędź J., Wspótczesna ekonomia. Ku nowemu paradygmatowi, C.H.Beck, Warszawa 2010.

Rudolf S., Nadzór korporacyjny w świetle analizy instytucjonalnej, [in:] S. Rudolf (ed.), Nowa ekonomia instytucjonalna wobec wspótczesnych problemów gospodarczych, WSEPiNM, Kielce 2014.

Schotter A., The Economic Theory of the Social Institutions, Cambridge University Press, Cambridge 2008.

Słomka-Gołębiowska A., Urbanek P., Wptyw nadzoru korporacyjnego na transparentność polityki wynagradzania kadry kierowniczej w bankach w Polsce, "Gospodarka Narodowa", Vol. 4/2015.

Uchwata Nr 17/1249/2010 Rady Nadzorczej Gietdy Papierów Wartościowych w Warszawie S.A. z dnia 19 maja 2010 roku w sprawie uchwalenia zmian "Dobrych Praktyk Spótek Notowanych na GPW" (Resolution No. 17/1249/2010 of the Warsaw Stock Exchange Supervisory Board of 19 May 2010 concerning adoption of amendments to "Code of Best Practice for WSE Listed Companies").

Uchwata Nr 19/1307/2012 Rady Nadzorczej Gietdy Papierów Wartościowych w Warszawie S.A. z dnia 21 listopada 2012 r. w sprawie uchwalenia zmian "Dobrych Praktyk Spótek Notowanych na GPW" (Resolution No. 19/1307/2012 of the Warsaw Stock Exchange Supervisory Board of 21 November 2012 concerning adoption of amendments to "Code of Best Practice for WSE Listed Companies").

Uchwata Nr 259/2011 Komisji Nadzoru Finansowego z dnia 4 października 2011 r. zmieniająca uchwate w sprawie szczegótowych zasad i sposobu ogtaszania przez banki informacji o charakterze jakościowym $i$ ilościowym dotyczacych adekwatności kapitatowej oraz zakresu informacji podlegajacych ogtaszaniu, Dz. Urz. KNF Nr. 8, poz. 39 (Resolution No. 259/2011 of the Polish Financial Supervision Authority of 4 October 2011 amending the Resolution on detailed rules and methods of publication of qualitative and quantitative information on capital adequacy by banks and the scope of published information, OJ of the KNF No. 8, item 39).

Urbanek P., Wynagrodzenia zarzadu w spótkach kapitatowych, PWE, Warszawa 2006. 